Vol. 1 No. 1, Maret 2021, hlm. 43 - 48

DOI: $\operatorname{xxxxxxxxxxxxxxxxx}$

Available online at http:// jurnal.stmikroyal.ac.id/index.php/j-com

\title{
ANALISIS PENYAKIT PADA TANAMAN CABAI DENGAN METODE CASE BASED REASONING BERBASIS WEB
}

\author{
Desi Ernawati ${ }^{1}$, Riki Andri Yusda ${ }^{2^{*}}$, Guntur Maha Putra ${ }^{3}$ \\ ${ }^{1}$ Mahasiswa Prodi Sistem Informasi, STMIK Royal \\ ${ }^{2}$ Prodi Teknik Komputer, STMIK Royal \\ ${ }^{3}$ Prodi Sistem Informasi, STMIK Royal \\ *email: rikiandriyusda@gmail.com
}

\begin{abstract}
Chili is a production cropthatis much needed by the community. Good care is needed to increase the production of chili plants. Production of chili plants will decrease if the types of diseases that attack are not considered. To find out about chili plant diseases, farmers only look at the disease without knowing the symptoms that appear beforehand so that it will affect the production of chili plants.So that we need experts who understand the symptoms of disease in chili plants. The existence of experts can be replaced by a system designed to detect symptoms of disease in chili plants. The expert system to be designed is web-based using the case-based reasoning method.This expert system is expected to help increase the productivity of chili plants.
\end{abstract}

Keywords:expert system; chili; case-based reasoning; chili plants.

\begin{abstract}
Abstrak:Cabai merupakan tanaman produksi yang banyak dibutuhkan oleh masyarakat. Untuk meningkatkan produksi tanaman cabai diperlukan perawatan yang baik. Produksi dari tanaman cabai akan menurun jika tidak diperhatikan jenis penyakit yang menyerang. Untuk mengetahui penyakit tanaman cabai para petani hanya melihat penyakitnya saja tanpa mengetahui terlebih dahulu gejala yang muncul sehingga akan mempengaruhi hasil produksi tanaman cabai. Sehingga diperlukan pakar yang mengerti mengenai gejala penyakit pada tanaman cabai. Keberadaan pakar bisa digantikan oleh sebuah sistem yang dirancang untuk mendeteksi gejala penyakit pada tanaman cabai. Sistem pakar yang akan dirancang berbasis web dengan menggunakan metode case base reasoning. Sistem pakar ini nantinya diharapkan membantu untuk peningkatan produktivitas tanaman cabai.
\end{abstract}

Kata kunci:sistem pakar; cabai; casebasereasoning; tanaman cabai.

\section{PENDAHULUAN}

Cabai merupakan salah satu tanaman rempah yang memiliki nilai ekonomi yang cukup tinggi. Cabai biasa digunakan sebagai bumbu masakan dan juga cabai dapat bermanfaat sebagai obatan tradisional, yang dapat menyembuhkan berbagai penyakit [1]. Cabai merupakan tanaman perdu yang dengan rasa pedas karena kandungan capsaicin yang berkhasiat sebagai stimulan. Cabai juga mengandung banyak gizi dan 
Vol. 1 No. 1, Maret 2021, hlm. 43 - 48

DOI: $\operatorname{xxxxxxxxxxxxxxxxx}$

Available online at http:// jurnal.stmikroyal.ac.id/index.php/j-com

vitamin, di antaranya kalori, protein, lemak, karbohidrat, kalsium, vitamin A, B1, dan vitamin C [2].

Seiring dengan peningkatan jumlah penduduk dan perkembangan dunia industri, maka kebutuhan akan cabai juga terus mengalami peningkatan. Pada tahun 2016 produksi cabai besar di Asahan mencapai 908 ton dengan rata-rata produksi 62,19 kw/ha. Jika dibandingkan dengan Tahun 2015 menurun 0,64\%. Kecamatan dengan produksi cabai terbesar adalah Sei Dadap dan Air Joman. Tahun 2019produksi cabai di kabupaten Asahan diperkirakan mencapai 665,8 ton (menurun 9,33\% dibandingkan tahun 2018 yang mencapai 712,9 ton).Daerah sentra produksi utama tanaman cabai untuk tahun 2019 antara lain Air Joman (52,3 ton) dan Rawang Panca (35,5 ton), berdasarkan data ini setiap kecamatan juga rata-rata mengalami penurunan produksi tanaman cabai (BPS Kabupaten Asahan, 2020).

Tanaman cabai sangat banyak dibudidayakan oleh para petani di Indonesia, sehingga prospek budidaya tanaman cabai menjadi usaha yang menjanjikan bagi para petani. Budidaya dengan sistem modern (intensif) dan sistem tradisional (ekstensif). Sistem intensif umum digunakan untuk meningkatkan produktivitas produksi tanaman cabai. Untuk peningkatan produksi tanaman cabai, petani menggunakan sistem pemupukan dan perawatan yang lebih intensif.

Hama dan penyakit senantiasa dijumpai pada tanaman pertanian, akan tetapi masalahnya adalah apakah hama atau penyakit tersebut menimbulkan kerugian atau tidak. Kesulitan untuk mengidentifikasi jenis hama dan penyakit yang menyerang tanaman cabai menjadi penyebab berkurangnya hasil produksi atau bahkan gagal panen. Petani kesulitan untuk mengetahui gejala atau tanda bahwa tanaman cabai sedang diserang hama dan penyakit. Sehingga pencegahan untuk penanggulangan hama dan penyakit yang diakibatkan oleh gejala yang muncul menjadi terlambat dilakukan. Kerugian yang paling banyak dialami pada tanaman cabai diakibatkan oleh penyakit bercak daun, penyakit antraknosa, penyakit tepung, penyakit busuk leher akar, penyakit fusarium, dan penyakit rebah semai [2].

Untuk mengatasi hal tersebut maka diperlukan penyuluh atau pakar dibidang tanaman cabai. Masalah yang muncul selanjutnya adalah ketersediaan pakar yang tidak senantiasa berada di tempat. Untuk itulah diperlukan sebuah sistem pakar yang menjadi pengganti penyuluh atau pakar. Sistem pakar adalah program berbasis pengetahuan yang menyediakan solusi-solusi untuk masalah-masalah dengan kualitas pakar[3].

Sistem pakar digunakan untuk meniru semua aspek yang ada dari kemampuan pengambilan keputusan berasal dari seorang pakar dan dengan menggunakannya secara maksimal untuk memecahkan suatu masalah dengan memanfaatkan teknologi AI [4]. Sistem pakar bisa dapat digunakan pada bidang apa saja, sehingga sistem pakar nantinya dapat menjadi pengganti pakar atau penyuluh agar pengetahuan pakar dapat diubah ke dalam bentuk sistem.

\section{METODE}

Metode yang digunakan adalah inference Case Base Reasoning (CBR). Case Based Reasoning adalah sistem yang ditujukan untuk penyelesaian suatu kasus baru dengan mengadaptasi solusi-solusi yang terdapat dalam kasus-kasus sebelumnya yang 
Vol. 1 No. 1, Maret 2021, hlm. 43 - 48

DOI: $\mathrm{xxxxxxxxxxxxxxxxx}$

Available online at http:// jurnal.stmikroyal.ac.id/index.php/j-com

mirip dengan kasus tersebut [5].

Inti dari CBR adalah memecahkan masalah berdasarkan permasalahan yang sudah pernah ada. Metode Case Based Reasoning memiliki 4 siklus yaitu meliputi: (1) Retrive, (2) Reuse., (3) Revise., (4) Retain [6].

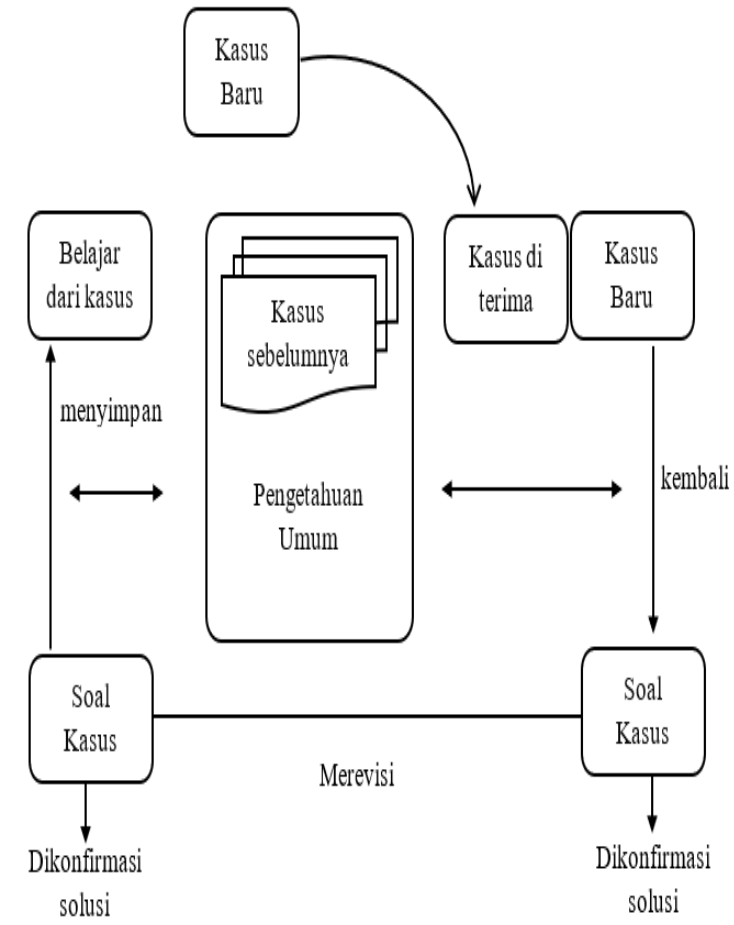

Gambar 1. Siklus Case Base Reasoning [7]

Teknik pengumpulan data yang dilakukan dalam penelitian ini adalah observasi, wawancara, dan studi pustaka [8]. Kerangka kerja penelitian dapat dilihat pada gambar di bawah ini.

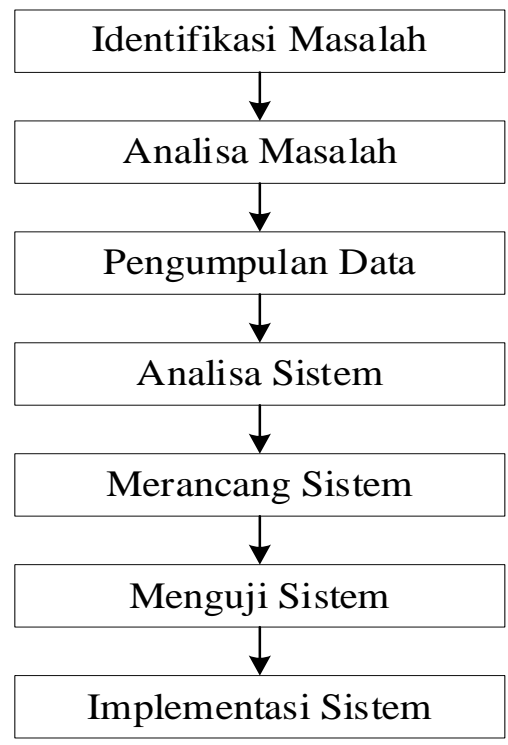

Gambar 2. Kerangka Kerja Penelitian 
Vol. 1 No. 1, Maret 2021, hlm. 43 - 48

DOI: $\operatorname{xxxxxxxxxxxxxxxxx}$

Available online at http:// jurnal.stmikroyal.ac.id/index.php/j-com

Langkah-langkah proses penelitian ini dijelaskan sebagai berikut: (1) Identifikasi Masalah, Mengidentifikasi masalah-masalah yang terdapat pada penentuan penyakit pada tanaman cabai dengan metode Case Based Reasoning berbasis web. Sehingga dapat diketahui masalah-masalah yang ada pada penelitian, proses, dan hasil pengenalan masalah atau inventarisasi masalah., (2) Analisa Masalah, Proses untuk memahami masalah apa yang sedang terjadi kemudian di analisa sehingga permasalahan yang telah ditemukan dan ditentukan tersebut dapat dipahami dan dicari solusinya., (3) Pengumpulan Data, Perbendaharaan konsep, kaidah, dan teori-teori yang mendukung dalam penelitian, Pengumpulan data dilakukan melalui wawancara langsung ke penyuluh atau pakar dan juga para petani., (4) Analisa Sistem, Data yang telah dikumpulkan di analisa untuk penyesuaian dengan analisa masalah. Analisa meliputi analisa fakta dan data yang diperoleh mengenai gejala dan penyakit pada tanaman cabai., (5) Merancang Sistem, Perancangan sistem meliputi perancangan model, perancangan sistem input beserta rule - rule yang digunakan dalam diagnosa penyakit tanaman cabai berbasis web, merancang Unified Modeling Language, dan merancang aplikasi., (6) Menguji Sistem, Pengujian sistem dengan prosedur untuk mencocokkan rule berdasarkan fakta yang akan dijadikan knowledgebase., (7) Implementasi Sistem, Pemakaian sistem secara langsung untuk mendeteksi dan memecahkan permasalahan mengenai deteksi penyakit pada tanaman cabai.

\section{HASIL DAN PEMBAHASAN}

Metode menggunakan Case Based Reasoning (CBR) serta menerapkan algoritme Nearest Neighbour. Pendekatan pada algoritma nearest neighbour dilakukan dengan mencari kasus dan menghitung kedekatan antara kasus baru dengan kasus lama berdasarkan pada pencocokan bobot dari sejumlah fitur yang ada [5].

Metode CBR memiliki empat proses yaitu: (1) Proses Retrieve, Proses diagnosa diawali dengan pengguna diminta memasukkan gejala-gejala yang dialami, selanjutnya sistem akan mengecek di basis pengetahuan untuk melakukan pembobotan dan pencocokan satu persatu antara gejala-gejala yang ada. Setelah itu baru ditentukan jenis hama dan penyakit yang menyerang tanaman cabai oleh sistem., (2) Proses Reuse, Pada proses reuse, solusi yang diberikan adalah dengan bobot kemiripan kasus yang paling tinggi. Dalam contoh ini adalah jenis hama thrips dengan nilai $28,84 \%$, dimana terdapat 1 (satu) gejala yang diinputkan memiliki kesamaan dengan gejala pada basis pengetahuan.Solusi pengobatan yang disarankan untuk kasus baru yang dimasukkan pengguna adalah pengendalian penyakit ini dengan pemberian insektisida confidor 200 LC, Agrimec 18 EC, dan mesureol $50 \mathrm{WP}$ sesuai dengan dosis pada kemasan label. (3) Proses Revise, Pada proses revise, solusi yang diusulkan ditinjau kembali kemudian diuji pada kasus yang nyata (simulasi) dan diperlukan untuk memperbaiki solusi agar cocok dengan kasus yang baru. (4) Proses Retain, Menyimpan kasus yang baru sehingga dapat digunakan sebagai pedoman untuk pembaharuan dalam basis pengetahuan selanjutnya.

Sistem pakar ini digunakan oleh para petani cabai mulai dari petani intensif dan ekstensif. Sistem berbasis daring sehingga dapat diakses oleh para petani untuk mendiagnosa hama dan penyakit kapanpun dan dimanapun. Untuk melakukan diagnosa, 
Vol. 1 No. 1, Maret 2021, hlm. $43-48$

DOI: $\operatorname{xxxxxxxxxxxxxxxxx}$

Available online at http:// jurnal.stmikroyal.ac.id/index.php/j-com

terlebih dahulu dilakukan registrasi pada sistem yang selanjutnya sistem akan memberikan pertanyaan mengenai gejala-gejala yang ada.

\section{SIMPULAN}

Penelitian yang telah dilakukan dan menghasilkan kesimpulan dalam perancangan sistem pakar diagnosa penyakit tanaman cabai dijadikan sarana konsultasi bagi para petani cabai dalam hal diagnosa penyakit dan hama tanaman cabai. Sistem ini membantu dalam hal mengetahui hama dan penyakit beserta solusi yang harus dilakukan untuk menanggulangi hama dan penyakit tersebut.

Metode case based reasoning dapat dengan cepat mengetahui jenis hama dan penyakit dengan membandingkan kasus baru dengan kasus yang tersimpan di basis pengetahuan dalam sistem. Logika kerja program yang diterapkan adalah nilai dari setiap similarity yang mempunyai nilai kemiripan yang paling tinggi. Sistem pakar ini masih dapat terus dikembangkan menambahkan basis pengetahuan baru dari hama dan penyakit pada tanaman cabai.

\section{DAFTAR PUSTAKA}

[1] R. S. Ferniah, S. Pujiyanto, and H. P. Kusumaningrum, "Indonesian red chilli (Capsicum annuum L.) capsaicin and its correlation with their responses to pathogenic Fusarium oxysporum," NICHE J. Trop. Biol., vol. 1, no. 2, p. 7, 2018, doi: 10.14710/niche.1.2.7-12.

[2] N. W. Suwardani, P. Purnomowati, and E. T. Sucianto, "KAJIAN PENYAKIT YANG DISEBABKAN OLEH CENDAWAN PADA TANAMAN CABAI MERAH (Capsicum annum L.) DI PERTANAMAN RAKYAT KABUPATEN BREBES," Scr. Biol., vol. 1, no. 3, p. 223, 2014, doi: 10.20884/1.sb.2014.1.3.554.

[3] N. I. Kurniati, H. Mubarok, and D. Fauziah, "Sistem Pakar Untuk Mendiagnosa Penyakit Hewan Peliharaan Menggunakan Metode Certainty Factor," J. Tek. Inform. dan Sist. Inf., vol. 4, no. 1, 2018, doi: 10.28932/jutisi.v4i1.708.

[4] F. A. El Hakim, H. Nurul, and R. K. Dewi, "Sistem Pakar Diagnosis Penyakit Telinga Hidung Tenggorokan (THT) Menggunakan Metode Naive Bayes Berbasis Android," J. Pengemb. Teknol. Inf. dan Ilmu Komput. Univ. Brawijaya, vol. 2, no. 4, pp. 1492-1500, 2018.

[5] S. Lestari, W. Diantoro, and F. I. Komputer, "Metode Case Based Reasonig (Cbr) Pada Sistem Diagnosa Penyakit Kulit," J. Inform., vol. 18, no. 1, pp. 21-34, 2018.

[6] I. Muzakkir and M. H. Botutihe, "Case Based Reasoning Method untuk Sistem Pakar Diagnosa Penyakit Sapi,” Ilk. J. Ilm., vol. 12, no. 1, pp. 25-31, 2020, doi: 10.33096/ilkom.v12i1.506.25-31.

[7] H. D. Hutahaean, "Penerapan Metode Case Based Reasoning Dalam Mengidentifikasi Kerusakan Kamera DSLR," J. Mantik Penusa, vol. 20, no. 1, pp. 87-90, 2016. 
Vol. 1 No. 1, Maret 2021, hlm. 43 - 48

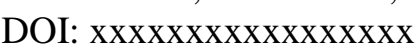

Available online at http:// jurnal.stmikroyal.ac.id/index.php/j-com

[8] I. Mahendra, F. Fadhilah, and I. Khairina, "Sistem Pakar Berbasis Web Menggunakan Metode Forward Chaining Untuk Mendiagnosa Penyakit Pulpa Dan Periapikal," JATISI (Jurnal Tek. Inform. dan Sist. Informasi), vol. 5, no. 2, pp. 177-193, 2019, doi: 10.35957/jatisi.v5i2.138. 